\title{
FLORISTIC AND STRUCTURAL CHARACTERIZATION OF THE MANGROVE FORESTS IN THE ESTUARY OF THE SÃO FRANCISCO RIVER
}

\author{
Tiago de Oliveira Santos ${ }^{1}$, Karen Viviane Andrade Santana ${ }^{2}$, Heide Vanessa Souza Santos ${ }^{2}$, Renisson \\ Neponuceno de Araújo Filho ${ }^{3}$, Francisco Sandro Rodrigues Holanda ${ }^{2 *}$

\footnotetext{
${ }^{1}$ Universidade Federal Rural de Pernambuco, Departamento de Agronomia, Recife, Pernambuco, Brasil - tiagoosantos@yahoo.com.br 2 *Universidade Federal de Sergipe, Departamento de Engenharia Agronômica, São Cristovão, Sergipe, Brasil - karenvivia@ hotmail.com; heidee.vanessa@gmail.com; fholanda@infonet.com.br
} \\ ${ }^{3}$ Universidade Federal do Tocantins, Departamento de Engenharia Florestal, Gurupi, Tocantins, Brasil-renisson@uft.edu.br
}

Recebido para publicação: 19/04/2017 - Aceito para publicação: 27/11/2018

\begin{abstract}
The objective of this work was characterize the floristic diversity and the phytosociological structure of the mangrove in the São Francisco River estuary in order to contribute to the conservation of this ecosystem. Thirtyfour sampling sites were selected, according to ongoing structural mosaic in the region ranging from 100 to $400 \mathrm{~m}$ between themselves, in a total useful area of $0.7625 \mathrm{ha}$. The evaluated parameters were: density of live and dead trunks; living and dead Basal Area; Absolute Frequency, Relative Frequency and Importance Value. Three typical mangrove species of the São Francisco estuary were found such as Avicennia germinans (L.) Stearn, Rhizophora mangle L. and Laguncularia racemosa (L.) Gaertn. F. Gaertn. The forest height ranged from 2.88 to $15.63 \mathrm{~m}$, the DBH from 3.95 to $19.74 \mathrm{~cm}$, live basal area from 4.22 to $47.83 \mathrm{~m}^{2} \mathrm{ha}^{-1}$ and dead basal area from 0.50 to $59.63 \mathrm{~m}^{2} \mathrm{ha}^{-1}$. The living trunks density ranged from 375.00 to 9100.00 trunks ha ${ }^{-1}$ and dead trunk density from 100-2800 trunks $\mathrm{ha}^{-1}$. The described results in this study demonstrated that the mangrove forests presents a structural variability that may be associated with environmental characteristics (marine erosion) and anthropogenic factors. The peculiarities of each site emphasize the importance of preventive actions in the ecosystem conservation.

Keywords: Avicennia germinans; Rhizophora mangle; Laguncularia racemosa; Phytosociology.
\end{abstract}

\section{Resumo}

Caracterização florística e estrutural das florestas de mangue no estuário do rio São Francisco. O objetivo deste trabalho foi caracterizar a diversidade florística e a estrutura fitossociológica do manguezal no estuário do rio São Francisco, a fim de contribuir para a conservação desse ecossistema. Para a amostragem, foram selecionados 34 bosques, segundo o mosaico estrutural presente na região, variando de 100 a $400 \mathrm{~m}$ entre si, totalizando uma área útil amostrada de 0,7625 ha. Os parâmetros avaliados foram: densidade de troncos vivos e mortos; área basal viva e morta; frequência absoluta; frequência relativa e valor de importância. Foram registradas três espécies típicas de mangue no estuário do rio São Francisco: Avicennia germinans (L.) Stearn, Rhizophora mangle L. e Laguncularia racemosa (L.) F. Gaertn. A altura média das árvores variou de 2,88 a $15,63 \mathrm{~m}$, o dap médio de 3,95 a 19,74 cm, a área basal viva de 4,22 a 47,83 $\mathrm{m}^{2}$.ha ${ }^{-1}$ e a área basal morta de 0,50 a 59,63 $\mathrm{m}^{2}$. ha $\mathrm{a}^{-1}$. Densidade de troncos vivos variou de 375 a 9100 troncos.ha $^{-1}$ e de troncos mortos de 100 a 2800 troncos.ha $^{-1}$. Os resultados descritos neste estudo demonstraram que o manguezal do estuário do rio São Francisco apresenta uma variabilidade estrutural que pode ser associada às características ambientais (erosão marinha) e fatores antrópicos. As peculiaridades de cada bosque ressaltam a importância de ações preventivas para a conservação desse ecossistema.

Palavras-chave: Avicennia germinans; Rhizophora mangle; Laguncularia racemosa; Fitossociologia.

\section{INTRODUCTION}

Mangroves are inserted in tropical and subtropical regions, being an authentic coastal forest whose structure and diversity of species are highly adapted to the topographical and geomorphological differences, saline fluctuations and tidal amplitudes. This ecosystem plays a key role in coastal geomorphological stability and biodiversity conservation (BARBIER et al., 2011).

Mangrove forests, although highly productive and located in legally protected areas, have changed their dynamics exponentially. The occupation of the coastline is configured as the main tensor agent in these environments, by promoting greater deforestation, landfills and dumping of sewage. These anthropogenic impacts

FLORESTA, Curitiba, PR, v. 49, n. 2, p. 163-170, abr/jun 2019.

Oliveira. T. S. et.al. 
can cause changes in the physical, chemical and biological properties of the ecosystem, directly reflecting the socioeconomic relations of the population dependent on this environment (MARTINS et al., 2011).

Based in the global estimates of Giri et al. (2011), it is possible to register a reduction of $14.548 \mathrm{~km}^{2} \mathrm{of}$ areas occupied by mangroves in a period of one year. According to ADEMA (2012), it is estimated that in the Sergipe state, the current area occupied by mangroves is approximately $256.26 \mathrm{~km}^{2}$ equivalent to $1.17 \%$ of the territory, distributed along $163 \mathrm{~km}$ of coast.

The municipality of Brejo Grande, located in the São Francisco estuary, presents the largest mangrove areas in the state of Sergipe, around $20392 \mathrm{~km}^{2}$, equivalent to $13.6 \%$ of the municipality area (ADEMA, 2012). However, in the last two decades, the changes introduced in the São Francisco river basin related to the indiscriminate use of land and control of the river flow by dams, are promoting changes in the dynamics of the estuary, being possible to observe a significant reduction of the area occupied by mangrove forests (SANTOS et al., 2011).

The main factors correlated with these losses of mangrove area are described by Blasco et al. (2001): deforestation, change of use and occupation of land, hydrological changes, pouring chemicals and climate change. Despite a wide structural variability, the number of plant species is reduced, since the mangrove ecosystem houses a typical vegetation adapted to the specific conditions of insolation, flood, salinity (MACEDO et al., 2007). Seven mangrove species occurring in Brazil are described: Rhizophora mangle L., Rhizophora harrisonii Leechm, Rhizophora racemosa G. Mey, Avicennias chaueriana Stapft e Leechm. Ex Moldenke, Avicennia germinans (L.) Stearn, Laguncularia racemosa (L.) F. Gaertne Conocarpus erectus Jacq. (SCHAEFFER-NOVELLI; CINTRÓN, 1986).

The structural characterization of forests can be divided into two types: horizontal and vertical. The first is analyzed through quantitative parameters that indicate the occupation of individuals in forest horizontal space, which are density, frequency and dominance, in absolute and relative terms (SANQUETA et al., 2009). The combination of these parameters provides the Importance Value - VI, which measures the share of each species relative to the other, and the verification of the form of their spatial distribution (SILVA et al., 2002). The second type of characterization is intended to indicate the stage of successional species within the forest. The study of the upper strata, middle and bottom allows the knowledge of the sociological position of existing species (FINOL, 1971). The combination of these analyses provides the amplified VI (VIA) of each species, featuring a phytosociological importance within the studied forest (SANQUETA et al., 2009).

The objective of this work was to characterize the floristic diversity and the phytosociological structure of the mangrove in the estuary of the São Francisco River in order to contribute to the conservation of this ecosystem.

\section{MATERIAL AND METHODS}

This study was conducted in the mangrove forests in the estuarine-lagoon region of the São Francisco River, located in the municipality of Brejo Grande (10 ${ }^{\circ} 25^{\prime} 38$ "South, $\left.36^{\circ} 28^{\prime} 12^{\prime \prime} \mathrm{W}\right)$, in Sergipe state, Northeastern Brazil. This municipality has an area of $149.2 \mathrm{~km}^{2}$ and is approximately $137 \mathrm{~km}$ to Aracaju, the state capital. It is limited to the North with the state of Alagoas; To the Northwest with the municipality of Ilha das Flores; To the east with the São Francisco River, to the west and southwest with the municipality of Pacatuba and to the south with the Atlantic ocean (ALVES et al., 2007).

According to ADEMA (2012), this estuary occupies an area of $35.31 \mathrm{~km}^{2}$, of which $20.39 \mathrm{~km}^{2}$ are covered by mangrove forests. The average annual temperature is $25^{\circ} \mathrm{C}$ and the annual rainfall average of $1201.7 \mathrm{~mm}$, with the heavy rainfall registered between the months of March to August. According to Koppen, the climate is classified as dry megathermal sub-humid.

For the vegetation characterization, we used a synthesis of the following works from Schaeffer-Novelli; Cintrón (1986) e Bernini; Rezende (2011), adopting the plots method, with adaptations to local conditions. Thirtyfour woods were selected by the structural mosaic present in the region ranging from 100 to $400 \mathrm{~m}$ apart, with a total useful area of 0.7625 ha sampled.

The selected forests were arranged according to the tidal flood gradient, in order to include in their characterization from fringe to transition and to dry land (Apicum or sandy cord). The delimitation of the forests was performed using compass, track and GPS. We consider the criteria for each sample considering all individuals with height greater than $1.0 \mathrm{~m}$, in order to measure the following variables: the Circumference at Breast Height $(\mathrm{CBH})$ or Circumference at Ground Height $(\mathrm{CGH})$, total height, Number of trunks per individual, description of the condition of the tree (living or dead), besides being annotated observations of the environment. The identification of plant species was carried out using the "Guide to the study of mangrove areas" (SCHAEFFERNOVELLI; CINTRÓN, 1986). It is important to emphasize that, despite the non replication, the size of the plots (forests) was defined to guarantee sample representativeness, and a plot is allocated to each differentiated physiognomy, varying from 100 to $400 \mathrm{~m}^{2}$, with a minimum of thirty (30) individuals per plot. 
After tabulating the data, the following parameters were calculated: Relative Density (RD) living and dead trunks = number of trunks / Grove area); The basal area of each species is obtained by the sum of the sectional areas $\left(\Sigma \mathrm{gi}=\left(\pi / 4 * \mathrm{DAP}^{2}\right)\right.$; Absolute Frequency $(\mathrm{AF})=$ (number of forests with occurrence of species $\mathrm{i} /$ total number of forests) $* 100$; Relative Frequency $(\mathrm{RF})=($ Absolute frequency of the species $\mathrm{i} / \Sigma$ of the absolute frequencies of all species considered in the survey)*100; Importance Value $(I V)=(R D+R F+D o R)$, which allows equal weights for the number of individuals and biomass (FELFILI; REZENDE, 2003). The diameter classes were established considering other phytosociological studies on mangroves, as provided by the current literature (SCHAEFFER-NOVELLI; CINTRÓN, 1986).

The MacGuinnes Index (IGA) was used to evaluate the species distribution. The STATISTICA 7.0 Software was performed with the collected samples data according to the relative density, very helpful in the identification of the homogeneity of this structural features of the São Francisco River estuary mangrove.

\section{RESULTS}

Three typical mangrove species were recorded in the São Francisco River estuary: Avicennia germinans (L.) Stearn, Rhizophora mangle L. and Laguncularia racemosa (L.) F. Gaertn. The spatial distribution of these species using MacGuinnes Index (IGA) has been classified as uniform for the $R$. mangle and aggregated to $L$. racemosa and $A$. germinans.

It was observed that the mangrove of the São Francisco estuary presents a heterogeneous structure development (Table 1) behaving differently among the 34 forests. The average height of the trees varied from 2.88 to $15.63 \mathrm{~m}$, the average diameter from 3.95 to $19.74 \mathrm{~cm}$, the living basal area from 4.22 to $47.83 \mathrm{~m}^{2} \mathrm{ha}^{-1}$ and the dead basal area from 0.50 to $59.63 \mathrm{~m}^{2} \mathrm{ha}^{-1}$. The density of live trunks ranged from 375 to 9100 trunks ha $^{-1}$ and dead trunks from 100 to 2800 trunks ha-1.

Table 1. Mangrove forest structural parameters of the São Francisco River Estuary, Brejo Grande, SE

Tabela 1. Parâmetros estruturais da floresta de mangue do estuário do rio São Francisco, Brejo Grande, SE

\begin{tabular}{|c|c|c|c|c|c|c|c|}
\hline $\begin{array}{c}\text { Sample } \\
\text { Unit }\end{array}$ & $\begin{array}{c}\text { Sample } \\
\text { Area }\end{array}$ & DTL & DTD & $\mathrm{ABL}$ & $\mathrm{ABD}$ & $\mathrm{AH}$ & $\mathrm{AD}$ \\
\hline $\mathrm{S} 1$ & 100 & 1200 & 800 & 13.12 & 7.07 & 7.48 & 11.18 \\
\hline $\mathrm{S} 2$ & 100 & 1300 & 500 & 10.75 & 3.20 & 8.14 & 10.69 \\
\hline S3 & 100 & 3600 & 2800 & 28.52 & 23.98 & 7.42 & 10.30 \\
\hline $\mathrm{S} 4$ & 400 & 775 & 1500 & 4.22 & 1.60 & 6.38 & 7.81 \\
\hline S5 & 100 & 2800 & 1100 & 24,94 & 5,19 & 8,62 & 9,90 \\
\hline S6 & 400 & 2075 & 275 & 14,68 & 1,46 & 7,60 & 8,44 \\
\hline S7 & 400 & 3750 & 2400 & 10,93 & 2,41 & 4,38 & 3,95 \\
\hline S8 & 400 & 1450 & 250 & 13,11 & 2,48 & 6,91 & 9,09 \\
\hline S9 & 400 & 1600 & 600 & 10,29 & 1,04 & 7,51 & 7,14 \\
\hline S10 & 100 & 3900 & 600 & 21,74 & 2,22 & 6,57 & 7,18 \\
\hline S11 & 100 & 3700 & 300 & 27,16 & 0,50 & 10,00 & 8,48 \\
\hline S12 & 100 & 6200 & 2700 & 16,05 & 2,93 & 5,07 & 4,51 \\
\hline S13 & 100 & 3800 & 1300 & 47,83 & 7,29 & 8,92 & 10,64 \\
\hline S14 & 400 & 2675 & 375 & 27.97 & 2.62 & 8.45 & 9.65 \\
\hline S15 & 100 & 6900 & 800 & 14.05 & 3.11 & 5.21 & 5.94 \\
\hline S16 & 100 & 2100 & 1600 & 23.65 & 10.92 & 5.43 & 10.58 \\
\hline S17 & 100 & 2000 & 600 & 28.97 & 5.09 & 8.85 & 12.15 \\
\hline S18 & 100 & 3300 & 400 & 32.43 & 0.50 & 8.36 & 8.49 \\
\hline S19 & 100 & 3300 & 1000 & 16.78 & 1.01 & 7.12 & 6.98 \\
\hline S20 & 100 & 4600 & 400 & 28.68 & 0.98 & 8.32 & 7.50 \\
\hline $\mathrm{S} 21$ & 400 & 2625 & 650 & 17.39 & 2.62 & 7.68 & 7.24 \\
\hline
\end{tabular}

FLORESTA, Curitiba, PR, v. 49, n. 2, p. 163-170, abr/jun 2019. 


\begin{tabular}{|c|c|c|c|c|c|c|c|}
\hline S22 & 400 & 5650 & 475 & 19.09 & 2.91 & 5.74 & 5.29 \\
\hline $\mathrm{S} 23$ & 400 & 1600 & 450 & 17.81 & 3.06 & 8.02 & 9.60 \\
\hline S24 & 400 & 1900 & 925 & 16.57 & 5.97 & 7.50 & 9.36 \\
\hline S25 & 225 & 1200 & 666.67 & 29.82 & 59.63 & 8.13 & 16.54 \\
\hline S26 & 100 & 2200 & 100 & 33.27 & 1.44 & 8.67 & 12.68 \\
\hline S27 & 100 & 3800 & 3200 & 27.76 & 31.62 & 5.00 & 8.31 \\
\hline S28 & 100 & 9100 & 2300 & 15.76 & 10.80 & 2.88 & 6.40 \\
\hline S29 & 225 & 844.44 & 622.22 & 15.30 & 3.39 & 9.23 & 12.69 \\
\hline S30 & 225 & 888.89 & 355.56 & 30.67 & 4.37 & 15.63 & 19.74 \\
\hline S31 & 225 & 800 & 266.67 & 25.01 & 2.41 & 15.50 & 19.28 \\
\hline S32 & 400 & 2325 & 275 & 27.43 & 6.46 & 5.38 & 7.05 \\
\hline S33 & 400 & 375 & 125 & 11.40 & 1.43 & 12.38 & 18.80 \\
\hline S34 & 225 & 3022.22 & 1688.89 & 31.79 & 13.64 & 10.40 & 10.17 \\
\hline
\end{tabular}

It was also observed a trend of structural patterns in the São Francisco mangrove forests, and is possible to affirm that the greater the distance of riverside communities and shrimp farms, the greater the structural development of the forests.

In general, the highest densities of living trunks were observed in forests S12, S15, S22, S28, and these forests are characterized by trees of small diameter, and sometimes by R. mangle and L. racemosa, or by R. mangle And A. germinans. In the field, it was possible to verify that these forests are subject to the constant stress of the marine erosion (S12), as well as of the anthropic interference (S15, S22 and S28) not allowing to reach maturity. The density of dead trunks was higher in S3, S7 and S12 forests (2800, 2400, 2700 trunks ha-1, respectively), and a large occurrence of termite mounds was recorded in these forests. The $R$. mangle species presented higher values in all parameters of the horizontal structure (Table 2), thus demonstrating a greater structural development.

Table 2. Mangrove forest horizontal structure of the São Francisco river estuary, Brejo Grande, SE Tabela 2. Estrutura horizontal das florestas de mangue do estuário do rio São Francisco, Brejo Grande, SE

\begin{tabular}{lccccccccccc}
\hline Species & $\mathrm{N}$ & $\mathrm{U}$ & $\mathrm{AB}$ & $\mathrm{AD}$ & $\mathrm{RD}$ & $\mathrm{AF}$ & $\mathrm{RF}$ & $\mathrm{ADo}$ & $\mathrm{RDo}$ & $\mathrm{IV}$ & $\mathrm{IV}(\%)$ \\
\hline R. mangle & 1474 & 34 & 11.072 & 1933.12 & 79.2 & 100 & 46 & 14.52 & 75.2 & 278.75 & 69.69 \\
L. racemosa & 269 & 24 & 2.1258 & 352.787 & 14.5 & 70.59 & 32.4 & 2.788 & 14.4 & 77.08 & 19.27 \\
A.germinans & 119 & 16 & 1.5361 & 156.066 & 6.39 & 47.06 & 21.6 & 2.015 & 10.4 & 44.16 & 11.04 \\
\hline Total & 1862 & 34 & 14,734 & 2441,97 & 100 & 217,7 & 100 & 19,32 & 100 & 400 & 100
\end{tabular}

$\mathrm{N}=$ Number of individuals; $\mathrm{U}=$ Number of forests that the species are inserted; $\mathrm{AB}=\mathrm{Sum}$ of cross-sectional area; $\mathrm{AD}=\mathrm{Absolute}$ Density (trunks ha ${ }^{-1}$ ); $\mathrm{RD}=$ Relative Density (trunks.ha ${ }^{-1}$ ); $\mathrm{AF}=$ Absolute Frequency; $\mathrm{RF}=\mathrm{Relative}$ Frequency; $\mathrm{ADo}=\mathrm{Absolute}$ Dominance $\left(\mathrm{m}^{2} \cdot \mathrm{ha}^{-1}\right)$; RDo= Relative Dominance $\left(\mathrm{m}^{2} \cdot \mathrm{ha}^{-1}\right)$; IV= Importance Value.

In the São Francisco mangrove, the magnitude of importance (IV) identified for the species in descending order was: R. mangle (69.69\%), L. racemosa (19.27\%) and A. germinans (11.04\%). In the case of the A. germinans species, few individuals were recorded, but with high altitude, suggesting that they are the oldest trees in the São Francisco estuary mangrove, and probably are being replaced in the natural forest (ecological succession) by individuals of $R$ mangle.It is important to note that $R$. mangle was recorded in all 34 study forests. In the vertical stratification, defined by the mean height of the individuals, the following strata were determined: lower (individuals with height less than / equal to $2.07 \mathrm{~m}$ ); (Between 2.07 and $11.03 \mathrm{~m}$ ) and higher (higher / equal to $11.03 \mathrm{~m}$ ), where there was a higher concentration in the intermediate class of height, which, when added to the three species, is composed of 1381 individuals (Figure 1). 


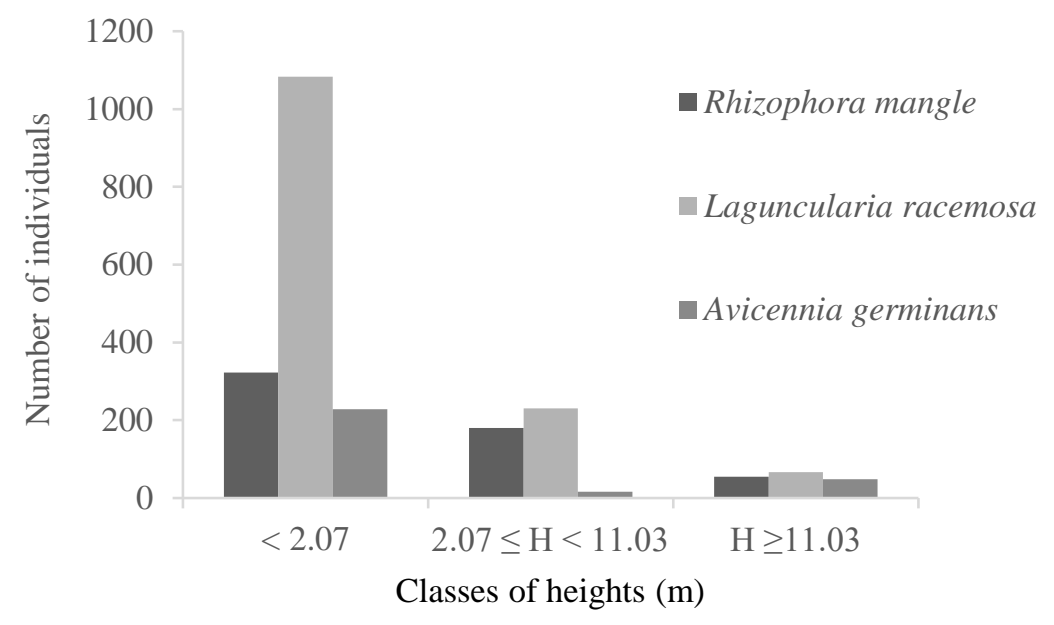

Figure 1. Mangrove vertical structure (height classes) of the São Francisco River estuary, Brejo Grande, SE.

Figura 1. Estrutura vertical (classes de altura) do manguezal do estuário do rio São Francisco, Brejo Grande, SE.

Adopting as a comparative description of Brazilian mangrove performed by Schaeffer-Novelli et al. (1990), in which the authors said that mature forests reach a little more than 10 meters in height, it can be stated that the São Francisco mangrove is in full development, seeking to reach its structural maximum. In all three strata, a dominance of $R$. mangle was noted.

With the distribution of individuals in diameter classes (Figure 2), a higher contribution of the species in the upper class $(\geq 10)$ was observed, leading to the understanding that the estuary of the São Francisco river presents a high structural development, and shows a good state of conservation, since, in addition to the three species, 425 seedlings and youngsters were qualified in the forests.

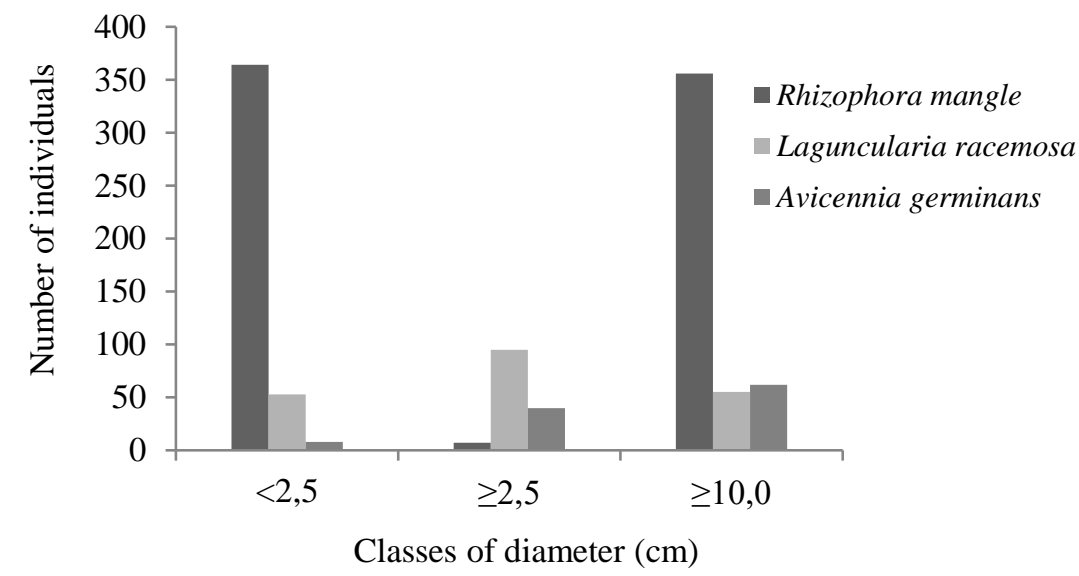

Figure 2. Distribution of the plants in diameter classes $(\mathrm{cm})$ by species of the mangrove of the São Francisco River estuary, Brejo Grande, SE.

Figura 2. Distribuição dos indivíduos em classes diamétricas $(\mathrm{cm})$, por espécie, do manguezal do estuário do rio São Francisco, Brejo Grande, SE.

R. mangle presented the highest number of individuals in the class $\geq 10$ and could be classified as dominant in the estuary. It is important to highlight the high number of young ones of this species in the studied forests, observed in the class $\geq 2.5$, can be understood as a process of the ecosystem renewal, considering the phenological characteristics of flowering, fruiting and dispersion of propagules of the species.

In addition, it is observed that the highest number of individuals of the L. racemosa species was limited to class $<10 \mathrm{~cm}$, according to Petri et al. (2011). This behavior is commonly observed in impacted areas. To infer that they are relatively juvenile forests. 


\section{DISCUSSION}

The low floristic diversity in the mangrove forests in relation to the other tropical forests, being associated to the specific conditions of this environment, allows a settlement by highly specialized species (MAIA et al., 2005).

In the floristic comparison of the present study with other works carried out in the mangroves of Sergipe state, such as in the Sergipe River mangrove (LANDIM; GUIMARÃES, 2006), the same species were observed as undoubted characteristics of this state mangroves.

The pattern described for forests in favorable environments was observed in forests S30, S31, S33, S34, which presented the highest mean height and diameter, being justified by the more distant location of the riverine communities, which reduces the impacts of the anthropogenic actions by the smaller. Accessibility to the site, and because it is a specific forest of $R$. mangle, characteristic of mature forests and without tensors.

In the present study, the distribution of individuals in diameter classes shows a behavior similar to that observed by Petri et al. (2011) in the mangrove of the Benevente River estuary in Anchieta State of Espirito Santo, Brazil.

The value of expanded importance (IV) synthesizes the horizontal and vertical structure of each species in a forest (SOUZA et al., 2007), being therefore the parameter that presents the best definition for the ecological importance of the species, observing its distribution. Not only from the horizontal or vertical point of view, but by the sum of the two analyzes (CIENTEC, 2006).

The dominance of $R$. mangle has been reported for Brazilian mangroves (MARTINS et al., 2011) and is related to the great dispersion and viability of propagules (JIMENEZ, 1985). This behavior is a guarantee of the permanence of the species in the phytochenosis since that, for Longhi et al. (1992), a species has a presence assured in the structure and dynamics of the forest when it is represented in all the strata.

The process of instant colonization in mangroves is justified by Tognella and Oliveira (2012) as a reflection of the low diversity, associated to the characteristics of each species by a distinct habitat, which leads to the formation of floristic and homogeneous structures. This fact ends up generating a small variation of diameter and height classes in most of the phytosociological studies in mangroves, making possible a more accurate comparison among the mangrove forests.

The lower number of L. racemosa individuals is probably due to the selective cut observed in some areas of the mangrove. However, for Cavalcanti et al. (2009), the most representative record of $R$. mangle is a strong indicator of preserved forests, because they are less tolerant to interference. A. germinans behaves differently from the other two species, with an increase in the number of individuals as the diameter increases, probably because they are being replaced in the São Francisco mangrove forests.

The exploitation of wood by the local population has gradually promoted a change in its architecture, being more branched and less developed. A differentiated behavior of the species is also observed as it moves away from the riparian communities. The current trends of extraction may threaten the distribution of L. racemosa in the São Francisco River mangrove, as observed by Rodríguez-Zúñiga et al. (2011) reporting similar pressure in the Alvarado mangrove, Veracruz, Mexico.

The results described in this study demonstrated that the mangrove São Francisco River estuary of the presents a structural variability that can be associated with environmental characteristics (marine erosion) and anthropic factors. The peculiarities of each forest highlight the importance of preventive actions for the conservation of this ecosystem.

\section{CONCLUSIONS}

- The mangrove presented heterogeneity in the structural development (behaving differently among the forests), possibly due to the distribution and architecture of the species and also in response to environmental tensors present in the area.

- Interspecific competition is probably influencing the spatial distribution of plant species in the region, since the forests of Avicennia germinans are being gradually replaced by L. racemosa and / or R. mangle.

- Rhizophora mangle was the dominant species in the São Francisco River estuary mangrove, presenting the highest phytosociological indexes.

- Laguncularia racemosa is the most exploited species by the local population in terms of wood, and has undergone a gradual change in its architecture, being more branched and underdeveloped. 


\section{REFERENCE}

ADMINISTRAÇÃO ESTADUAL DO MEIO AMBIENTE (ADEMA). Seminário do Levantamento Quantitativo do Manguezal de Sergipe. Disponível em: 〈http://www.adema.se.gov.br/modules/news/article〉 Acesso em: 01 out. 2012.

ALVES, N. M. S.; FONTES, A. L.; SILVA, D. B.; ALMEIDA, J. A. P. Dinâmica geoambiental, processos morfodinâmicos e uso das terras em Brejo Grande, Baixo São Francisco - Sergipe. Revista Brasileira de Geomorfologia, São Paulo, v. 8, n. 2, p. 11-21, 2007.

BARBIER, E. B.; HACKER, S. D.; KENNEDY, C.; KOCH, E. W; STIER, A. C.; SILLIMAN, B. R. The value of estuarine and coastal ecosystem services. Ecological Monographs, Washington, v. 81, n. 2, p. 169-193, 2011.

BERNINI, E.; REZENDE, C. E. Vegetation structure in a mangrove forest in Southeastern Brazil. Pan-American Journal of Aquatic Sciences, Rio Grande do Sul, v. 6, n. 3, p. 193-209, 2011.

BLASCO, F.; AIZPURU, M.; GERS, C. Depletion of the mangroves of Continental Asia. Wetlands Ecology and Management, Berlin, v. 9, n. 3, p. 255-266, 2001.

CAVAlCANTI, V. F.; SOARES, M. L. G.; ESTRADA, G. C. D.; CHAVES, F. O. Evaluating mangrove conservation through the analysis of forest structure data. Journal of Coastal Research, Flórida, v. 56, n.1, p. 390-394, 2009.

CIENTEC. Software Mata Nativa 2: Sistema para Análise Fitossociológica, Elaboração de Inventários e Planos de Manejo de Florestas Nativas. Viçosa - MG: Cientec, 2006.

FELFILI, J. M.; REZENDE, R. P. Técnicas florestais:Conceitos e métodos em fitossociologia. Brasília: UNB, 2003, 68 p.

FINOL, H. Nuevos parâmetros a considerar-se en el análises estructural de las selvas virgenes tropicales. Revista Forestal Venezoelana, Merida, v. 14, n. 21, p. 24-42, 1971.

GIRI, C., OCHIENG, E., TIESZEN, L.L., ZHU, Z., SINGH, A., LOVELAND, T., MASEK, J., DUKE, N. Status and distribution of mangrove forests of the world using earth observation satellite data. Global Ecology and Biogeography, Arizona, v. 20, n.1, p. 154-159, 2011.

JIMENEZ, J.A. Rhizophora mangle L. Red mangrove. Publication SO-ITF-SM-2. Rio Piedras, PR: U.S. Department of Agriculture, Forest Service, Southern Forest Experiment Station, Institute of Tropical Forestry. 1985, 7 p.

LANDIM, M.; GUIMARÃES, C. P. Manguezais do Rio Sergipe. In: ALVES, J. P. Rio Sergipe: importância, vulnerabilidade e preservação. São Cristóvão: Editora UFS, 2006, 221 p.

LONGHI, S. J.; SELlE, G. L.; RAGAGNIN, L. I. M.; DAMIANI, J. E. Composição florística e estrutura fitossociológica de um "Capão " de Podocarpus lambertii Klotz, no Rio Grande do Sul. Ciência Florestal, Santa Maria, v. 2, n.1, p. 9-26, 1992.

MACEDO, T. S.; FERNANDES, L. L; SILVA, D. F. da; VARJÃO, A. S.; NEVES, A. S. das; PIGOZZO, M. C. Comparação florística entre um fragmento de mata atlântica e ambientes associados (restinga e manguezal) na cidade de Salvador, Bahia. Candombá - Revista Virtual, Salvador, v. 3, n. 2, p. 138-148, 2007.

MAIA, L. P.; LACERDA, L. D.; MONTEIRO, L. H. U.; SOUZA, G. M. E. Atlas dos Manguezais do Nordeste: Avaliação das Áreas de Manguezal dos Estados do Piaú, Ceará, Rio Grande do Norte, Paraíba e Pernambuco. Superintendência Estadual do Meio Ambiente, Fortaleza, 2005.

MARTINS, P. T. de A.; COUTO, E. C. G.; DELABIE, J. H. C. Phytosociology of the Cururuperiver Mangrove (Ilhéus, Bahia State, Brazil) Journal of Integrated Coastal Zone Management, Lisboa, v. 11, n. 2, p. 163-169, 2011.

PETRI, D. J. C.; BERNINI, E.; SOUZA, L. M.; REZENDE, C. E. Species distribution and structure of mangrove of the Benevente River, Anchieta, ES. Biota Neotropical, Campinas, v. 11, n. 3, p. 107-116, 2011.

RODRÍGUEZ-ZÚÑIGA，M. T.; RAMÍREZ-GARCÍA，P.; GUTIÉRREZ-GRANADOS，G. Efectos de la extracción no controlada de madera sobre la comunidad y estructura de tamaños de los manglares de Alvarado, Veracruz, México. Boletín de la Sociedad Botánica de México, México, v.1, n.89, p. 107-113, 2011. 
SANQUETA, C. R; WATZLAWICK, L. F.; CÔRTE, A. P. D.; FERNANDES, L. de A. V.; SIQUEIRA, J. D. P. Inventários florestais: Planejamento e execução. Curitiba, 2 ed. 2009, 316 p.

SANTOS, H. V. S.; SANTOS, T. O.; HOLANDA, F. S. R. Indicadores para diagnóstico das alterações antrópicas no manguezal do estuário do rio São Francisco. Tropical Oceanography, Recife, v. 39, n. 2, p. 166-178, 2011.

SCHAEFFER-NOVELLI, Y.; CINTRÓN, G. Guia para estudo de áreas de manguezal: Estrutura, função e flora. Caribbean Ecological Research, São Paulo, 1986, 150 p.

SCHAEFFER-NOVELLI, Y.; CINTRÓN-MOLERO, G.; ADAIME, R. R.; CAMARGO, T. M. de. Variability of Mangrove Ecosystems along the Brazilian Coast. Estuaries and Coasts, New York, v. 13, n. 2, p. 204-218, 1990.

SILVA, L. O.; COSTA, D. A.; FILHO, K. do E. S. FERREIRA, H. D.; BRANDÃO, D. Levantamento florístico e fitossociológico em duas áreas de cerrado sensu stricto no Parque Estadual da Serra de Caldas Novas, Goiás. Acta Botanica Brasilica, Belo Horizonte, v. 16, n. 1, p. 43-53, 2002.

SOUZA, F. N. de; ARAÚJO, E. J. G. de; MELLO, J. M. de; SCOLFORO, J. R. S.; SILVA, C. P. de C. Composição florística e estrutura de dois fragmentos de floresta estacional semidecidual na bacia do Rio Grande, Minas Gerais. Revista Brasileira de Biociências, Porto Alegre, v. 5, n. 2, p. 183-185, 2007. Nota científica.

TOGNELLA, M. M. P.; OLIVEIRA, R. G. de. Manguezal do rio Camboriú: Dados preliminares. Enciclopédia Biosfera, Goiânia, v. 8, n. 15, p. 1828-1844, 2012. 